\author{
Anna Nacher \\ ORCID: 0000-0002-3192-2724 \\ Uniwersytet Jagielloński
}

\title{
Obserwuj, reaguj, odkrywaj. Permakultura przeciw agrologistyce ${ }^{*}$
}

Abstrakt: Artykuł został poświęcony potencjałowi permakultury jako praktyki wykraczającej poza formy trwałego (zrównoważonego) rolnictwa. Autorka wskazuje w nim na to, że zestaw odpowiedzi na aktualne kryzysy ekologiczne wypracowanych w ramach permakultury zawsze zależy od kontekstów konkretnego ekosystemu, opartych na elastyczności i nie kieruje się dogmatycznymi przesłankami w rozwiązywaniu problemów. Permakultura jest zatem nie tylko praktyką nakierowaną równocześnie na uprawę ziemi w zrównoważony sposób i na wzmacnianie obfitości plonów, lecz także na utrzymywanie związków z dawnymi formami postępowania protonaukowego, często inspirowanymi przez rdzenne formy wytwarzania wiedzy. Proponuje więc postrzeganie etyki i podejścia permakulturowego jako ,misji bez misji” i przeciwstawia je nowoczesnemu przekonaniu o tym, co ustanawia społecznie progresywne i ekologicznie sensowne działanie.

Słowa-klucze: permakultura, kryzysy ekologiczne, agrologika, antropocen, transcdyscyplinarność

Opierając się na doświadczeniach transdyscyplinarnych, obejmujących zarówno aktywność w ruchu ekologicznym lat dziewięćdziesiątych, praktykę terenową w niewielkim gospodarstwie permakulturowym Biotop Lechnica na pograniczu polsko-słowackim ${ }^{1}$, jak i pracę teoretyczną stanowiącą sedno mojej praktyki akademickiej, chciałabym kontynuować przy tej okazji wątki podjęte kilka lat temu w książce poświęconej pograniczom kultury popularnej, a dokładniej temu, co stało się z kontrkulturą w początkach XXI wieku². Tym razem chciałabym przyjrzeć się przede wszystkim ruchowi i zjawisku, które śmiało można nazwać „,ichą

${ }^{*}$ Konsultacja z zakresu ekologii systemowej, praktyki permakultury i leśnictwa - mgr inż. Marek Styczyński, współgospodarz Biotopu Lechnica.

${ }^{1}$ Do tych doświadczeń odwołuję się między innymi w haśle Zamieszkiwanie napisanym na potrzeby Słownika przyszłości, powstałego w ramach Forum Przyszłości Kultury: http://forumprzyszloscikultury.pl/upload/2018/12/zamieszkiwanie-a-nacher.pdf (dostęp: 20.09.2019). Por. także strona domowa Biotopu Lechnica: http://biotoplechnica.eu (dostęp: 20.09.2019).

2 A. Nacher, Rubieże kultury popularnej. Popkultura w świecie przeptywów, Poznań 2012. Książka w całości dostępna na stronie internetowej autorki: https://nytuan.files.wordpress.com/2014/12/ rubieze-blok-kor.pdf (dostęp: 20.09.2019). 
rewolucją", czyli permakulturze, a przede wszystkim sposobowi formułowania odpowiedzi - zawsze uzależnionych od lokalnego kontekstu i pozostających w dialogu z otoczeniem — na znaczące kryzysy naszej współczesności.

Chcę zatem pokazać, że w projektowaniu permakulturowym kryje się cała gama rozwiązywań dla wielu palących problemów ekologicznych naszej współczesności. Oferują one przy tym tryb postępowania niezwykle wyczulony na kontekst i warunki konkretnych ekosystemów, a zarazem wolność od sztywnych dogmatyzmów i pragmatyczną elastyczność przy jednoczesnej dbałości o solidne podstawy etyczne, budowane na etyce troski, ale rozumianej w sposób wykraczający poza ograniczenia związane z gorsetem tradycyjnych ról płciowych. Permakultura ucieleśnia przy tym transdyscyplinarny obieg wiedzy krążącej między interdyscyplinarną podbudową teoretyczną i naukową a nader namacalną i materialną praktyką pracy z ziemią, która wyciąga wnioski z klęsk rolnictwa przemysłowego. Dlatego warto przyjrzeć się jej nie tylko jako jednej z odmian alternatywnego rolnictwa, lecz także jako szerszej kulturowej formule „misji bez misji” oraz sposobowi prowadzenia refleksji sympoietycznej, ulokowanej nieco (czasem dosłownie) bliżej ziemi/Ziemi niż w mocno już spetryfikowanej refleksji wokół antropocenu. Permakultura jest też swoistym rewersem tej debaty —oferującym nadzieję w rozumieniu nie tyle kulturowej fantazji o zbawieniu ${ }^{3}$, ile raczej „,nadziei w mroku”4.

\section{Zamiast metody — poza pytania badawcze i ewentualne odpowiedzi}

Chcę przy tym przyjąć odmienny sposób postępowania - w miejsce wprost wyartykułowanych pytań badawczych i odpowiedzi na nie po przeprowadzeniu argumentacji chciałabym raczej przyjąć postawę eksploracyjną, bliższą opisowi gęstemu. Nie zamierzam także kryć się za złudnym przekonaniem, że jasne odpowiedzi dają się wyartykułować w sposób nieproblematyczny. Zamierzam bowiem przyjrzeć się permakulturze w perspektywie nieco odmiennego kształtowania relacji refleksji humanistyki z ekologią społeczną, gdyż dotychczasowe praktyki w tym obszarze - oraz amplituda sukcesów i porażek — mogą niekiedy napawać niepokojem. Znaczenie ma tutaj właśnie owa wspomniana już transcydyscyplinarność permakultury, którą jednak niezupełnie daje się sprowadzić do formuły humanistyki zaangażowanej, gdyż żywioł społeczny nie jest tutaj definiowany jako odrębny wobec praktyki realizowanej pozornie w odmiennym obszarze

3 J. Franzen, What if we stopped pretending, „The New Yorker” 8.09.2019, https://www.newyorker.com/culture/cultural-comment/what-if-we-stopped-pretending?fbclid=IwAR2KQDkoXuBp5MW tTraO9qGRR7QU20L3vGtC34QluAI0lc6LQ_qqM-S2Vz0 (dostęp: 9.09.2019).

${ }^{4}$ R. Solnit, Nadzieja w mroku, przeł. A. Dzierzgowska, S. Królak, Kraków 2019. 
(przyrodniczym). Warto przy tym zauważyć, że rozumienie transdyscyplinarności ma związek z kontekstem badań środowiskowych prowadzonych w Niemczech i Szwajcarii na przełomie lat osiemdziesiątych i dziewięćdziesiątych. Proponowano wtedy uznanie potrzeby kształtowania raczej wspólnych pytań badawczych i praktyk dla konkretnych problemów występujących w świecie doświadczeniowym (Lebenswelt) niż odrębnych dyscyplin. Miało to ułatwiać porozumienie między sektorami: światem akademickim i społecznym, politycznym czy ekonomicznym ${ }^{5}$. Nic dziwnego, jedna z definicji badań transdyscyplinarnych głosi bowiem: „Badania transdyscyplinarne są nakierowane na lepsze dopasowanie produkcji wiedzy akademickiej do społecznych potrzeb rozwiązywania, niwelowania lub zapobiegania takim problemom, jak przemoc, choroby lub degradacja środowiska"6.

W tym kontekście niepokoić może dzisiaj przede wszystkim to, że choć zręby badań transdyscyplinarnych $\mathrm{w}$ tym zakresie zostały zarysowane ponad trzy dekady temu i że w dobie zmian klimatycznych tematyka ekologiczna praktycznie nie schodzi z czołówek portali i szczelnie wypełnia strumień aktualności w mediach społecznościowych, to nie prowadzi to do podejmowania działań politycznych na stosowną skalę. Doniesienia na ten temat są poza tym utrzymywane zazwyczaj w tonie apokaliptycznym, co w gruncie rzeczy często osłabia motywację do działania; tematyka bywa także instrumentalizowana lub odgrywa rolę swoistego alibi mającego zastąpić konkretne działania na rzecz zmiany nawyków, praktyk i upodobań. A zatem warto poszukać innych jeszcze metod i praktyk, które dotyczą także sfery motywacji, nie tylko organizacji informacji czy transmisji wiedzy.

Problematyka ta nie jest przy tym aż tak nowa, jak można byłoby sądzić pierwsze badania nad antropogenicznymi zmianami klimatycznymi były prowadzone w latach pięćdziesiątych XX wieku. Ich pochodną jest między innymi słynna krzywa Keelinga obrazująca nasycenie atmosfery Ziemi $\mathrm{CO}_{2}$, do dziś stanowiąca podstawę wielu form wizualizujących zmianę w tym zakresie ${ }^{7}$. Jeżeli zaś obecnie czytamy atrakcyjne retorycznie, pobudzające wyobraźnię tezy o „szóstym wymieraniu" 8 i dobitnie krytykujemy rozliczne terrory i horrory niekontrolowanej konsumpcji, to trzeba pamiętać, że jednym z pierwszych impulsów kierujących uwagę ku zagrożeniu, jakie niesie dla ekosystemów działalność ludzka, był słyn-

5 J.T. Klein, A taxonomy of interdisciplinarity, [w:] The Oxford Handbook of Interdisciplinarity, red. R. Frodeman, J. Thompson Klein, C. Mitcham, Oxford 2010, s. 15-31.

${ }^{6}$ G. Hirsch Hadorn, Ch. Pohl, G. Bammer, Solving problems through transdisciplinary research, [w:] The Oxford Handbook of Interdisciplinarity..., s. 431-434; jeśli nie podano inaczej, przeł. A.N.

${ }^{7}$ Ch.D. Keeling, The concentration and isotopic abundances of carbon dioxide in the atmosphere, „Telus” 12, 1960, nr 2, s. 200-203. Sięgam do tych wątków także w rozdziale Antycypacje poza ludzkim horyzontem - ćwiczenia z wielowymiarowości? przygotowywanym do druku w tomie zbiorowym planowanym przez Instytut Kultury Polskiej.

${ }^{8}$ E. Kolbert, Szóste wymieranie. Historia nienaturalna, przeł. T. Grzegorzewska, P. Grzegorzewski, Warszawa 2016. 
ny raport U. Thanta, przedstawiony na Zgromadzeniu Ogólnym ONZ w sierpniu $1969 \mathrm{roku}^{9}$. W międzyczasie, w 1962 roku, ukazała się słynna książka Rachel Carson - Silent Spring ${ }^{10}$, w której znana i ceniona już wtedy autorka bestsellerów o tematyce przyrodniczej (w tym tak zwanej trylogii morskiej) zdawała relację ze szkodliwości pestycydów, powszechnie stosowanych w latach pięćdziesiątych zarówno w amerykańskim rolnictwie przemysłowym, jak i w przydomowych ogródkach. Była to publikacja, po której chora wówczas na raka piersi Carson stała się ikoną amerykańskiego ruchu ekologicznego i jednocześnie przedmiotem bezpardonowych ataków ze strony amerykańskiego przemysłu chemicznego, szukającego po zakończeniu II wojny światowej nowych rynków i nowych zastosowań - poza potrzebami militarnymi ${ }^{11}$. Dzisiaj wprawdzie tematyka pozostaje wciąż aktualna $^{12}$, ale z pewnością jest tematem na tyle dobrze oswojonym, że znajduje sobie drogę do tekstów kultury popularnej. Jednym z nowszych przykładów jest miniserial wyemitowany w 2019 roku przez stację ARTE, a zrealizowany przez Jeana-Xaviera de Lestrade (znanego z oscarowego dokumentu z 2002 roku, Un coupable idéal) - Jeux d'influences, z głównym wątkiem tematycznym obejmującym walkę o zakaz stosowania glifosatu we Francji, opartym na walce francuskiego rolnika Paula François z koncernem Monsanto ${ }^{13}$.

Żyjemy zatem w świecie, w którym z jednej strony tematyka ekologiczna staje się chlebem powszednim współczesnej mediasfery, z drugiej - równie często ulega banalizacji, instrumentalizacji lub wpisuje się w mechanizmy tak zwanego greenwashing. Tym mianem określa się strategię marketingową opracowaną i zastosowaną na znaczącą skalę w latach dziewięćdziesiątych XX wieku, kiedy mieliśmy do czynienia $\mathrm{z}$ poprzednią falą zainteresowania aktywnością społecznych ruchów ekologicznych. Wydawało się wtedy — tak jak wydaje się dzisiaj — że podjęte na globalną skalę tematy niszczenia dzikiej przyrody oraz krytyka niekontrolowanego wzrostu gospodarczego kosztem natury przełożą się na znaczące

${ }^{9} \mathrm{U}$. Thant, Problems of the human environment; report of the Secretary-General, dokumenty ONZ E/4667; żadna z wersji raportu nie jest obecnie dostępna online.

${ }^{10}$ R. Carson, Silent Spring \& Other Writings on the Environment, red. S. Steingraber, New York 2018 (to obecnie najnowsze wydanie tej fundamentalnej książki).

11 Interesujące reinterpretacje propozycji Carson z punktu widzenia późniejszych postaw interdyscyplinarnych przynosi wstęp Sandry Steigreber. Por. obszerne omówienie nowego wydania dzieł zebranych R. Carson, M. Crist, A strange blight, „London Review of Books” 41, 2019, nr 11, s. 3-7.

12 Jak bardzo, pokazuje dokumentacja zamieszczona na stronach amerykańskiej kancelarii prawnej, prowadzącej pozew przeciw Monsanto. Strona internetowa Baum, Hedlund, Aristei, Goldman, Where is Glyphosat banned?, https://www.baumhedlundlaw.com/toxic-tort-law/monsanto-roundup-lawsuit/where-is-glyphosate-banned/?fbclid=IwAR0cAkounL19rQxUz_06L5Fni-TNkIA4NP8zN-0YTVO0--loi2JbJWR4HT4 (dostęp: 1.09.2019).

13 Jeux d'influence, reż. J.X. de Lestrade, France 2019 (serial emitowany w Arte France między 13 a 27 czerwca 2019 roku). Por. A. Massiot, Jeux d'influence, l'affaire Monsanto revisitée en série, „Libération” 7.06.2019, https://www.liberation.fr/planete/2019/06/07/jeux-d-influence-1-affaire-monsanto-revisitee-en-serie_1732055 (dostęp: 28.06.2019).

Prace Kulturoznawcze 23, 2019, nr 2-3

(C) for this edition by CNS 
zmiany ekonomiczne, kulturowe i społeczne. Tak się jednak nie stało, czego najlepszym przykładem są spektakularne klęski na arenie międzynarodowej (czy ktoś jeszcze pamięta o słynnym protokole z Kioto, którego konsekwencją był równie kontrskuteczny protokół paryski, czy o tak zwanej Agendzie 21 z Rio de Janeiro?) oraz codzienne doniesienia o świecie antropocenu, radykalnie przekształconym przez działalność człowieka ${ }^{14}$. W roli symbolu klęski ruchów ekologicznych lat dziewięćdziesiątych można byłoby obsadzić recykling — głównego dyskursywnego bohatera ówczesnych narracji (zarówno w środowisku ekologicznym, jak i w biznesie). O jego (braku) skuteczności możemy przekonać się dzisiaj, oglądając globalne próby radzenia sobie z imponującymi śmietnikami oceanicznymi. Popularnemu zainteresowaniu tematyką ekologiczną i podejmowaniu licznych rozproszonych działań na rzecz zmiany towarzyszy twórczy ferment teoretyczny. Dyskusja na temat kolejnych weryfikacji i redefinicji granic między kulturą a naturą oraz debata o rozmaicie nazywanych ,-cenach” (antropocen, kapitałocen, nekrocen itp.) bywa niezwykle owocna, twórcza i inspirująca. Wydaje się jednak także, że wysiłki humanistów nierzadko ograniczają się do dosyć jednak hermetycznego kręgu akademickiej wymiany (chwalebnym wyjątkiem może być przywołana już książka Ewy Bińczyk) i predylekcji do analiz w paradygmacie reprezentacjonistycznym (być może to zresztą bolączka nieuchronna...) $)^{15}$.

Wprowadzam ten minorowy nastrój po to, żeby wskazać przede wszystkim na palącą potrzebę autorefleksji po obu stronach umownej barykady: akademickiej i społecznej. Wnikliwe analizy kolejnych porażek są bowiem niezbędne jako faza uczenia się — choćby po to, żeby aktualna fala sprzeciwu spod znaku Extinction Rebellion czy Obozu dla Klimatu nie powtórzyła przegranej batalii z nie mniej

${ }^{14}$ Przyczyny i oblicza takich porażek wnikliwie analizuje Ewa Bińczyk w wydanej niedawno książce poświęconej kategorii antropocenu - eadem, Epoka człowieka. Retoryka i marazm antropocenu, Warszawa 2018. To znakomita i bardzo potrzebna (zwłaszcza w polskich warunkach) publikacja, która wpisuje się jednak w zdecydowanie bardziej dzisiaj popularny tryb krytyczny i katastroficzny. Choć tego rodzaju opracowania bez wątpienia są niezbędne, warto chyba uzupełnić je o artykulację programu pozytywnego, czyli projektowanie możliwości realnej zmiany. W niniejszym tekście chcę więc zaoferować drobne uzupełnienie, sygnalizując przede wszystkim istnienie sprawdzonych i działających alternatyw. Uważam to za niezbędny, kolejny — po wykonaniu rzetelnej krytyki — krok.

15 Takie tendencje można dostrzec w niemal wszystkich, skądinąd znakomitych, artykułach zamieszczonych w fascynującym numerze „Prac Kulturoznawczych” (22, 2018, nr 1-2) poświęconym tematyce antropocenu. Przy ogromnej wartości opublikowanych w czasopiśmie materiałów jest trochę tak, jakby terminologiczne i konceptualne weryfikacje styku żywego i nieożywionego nie przekładały się na konieczne przemyślenie podstaw praktyki akademickiej doby zmiany klimatycznej i rozlicznych kryzysów/,,-cenów”. To aspekt o tyle istotny, że bez koniecznej transdyscyplinarności, czyli przeprowadzenia mocnych i szerokich mostów między wzmożoną wymianą na gruncie akademickim a praktyką społeczną oferującą równie żywiołowy potencjał pracy na rzecz zmiany, nie da się wyjść poza zaklęty krąg klęsk społecznego ruchu ekologicznego w Polsce. Pozwoliłoby to również uniknąć wyważania otwartych drzwi po obu stronach — akademickiej i aktywistycznej. Myśl tę mam nadzieję rozwinąć w innej formie w najbliższej przyszłości.

Prace Kulturoznawcze 23, 2019, nr 2-3

(C) for this edition by CNS 
niż w poprzednich dekadach zachłannymi wielkimi rynkowymi graczami. Środowiska aktywistyczne zazwyczaj bywają dyskursywnie obsadzone w rolach, które służą raczej cementowaniu antyekologicznego porządku społecznego, niż w jakikolwiek sposób go naruszają. Doniesienia medialne o ,protestujących ekologach” stanowią jedną z najbardziej przewidywalnych form kształtowania dyskursu wokół problematyki ekologicznej, co samo w sobie odwraca uwagę od mniej spektakularnych, koniecznych do podjęcia działań w skali mikro, mezo i makro. To zaś nieuchronnie prowadzi do marginalizowania debaty ekologicznej — taka analiza musiałaby jednak być przedmiotem odrębnego tekstu, na razie pozostawię więc ten wątek na marginesie.

\section{Cicha rewolucja, czyli misja bez misji}

W gruncie rzeczy mamy bowiem do czynienia z amplitudą skuteczności społecznego ruchu ekologicznego (w rozmaitych zresztą jego granularnościach), w której spektakularne sukcesy - jak współudział niemieckiej partii Zielonych (a dokładniej Bündnis 90/Die Grünen) w koalicji rządowej lat 1998-2005 — przeplatają się z równie znaczącymi klęskami - jak niemożność wprowadzenia trwałych polityk klimatycznych na skalę międzynarodową. Takie fluktuacje mogą być postrzegane jako swoisty efekt uboczny dyskursu misji, definiowanej na sposób, do którego przyzwyczaiła nas europejska (zachodnia) nowoczesność. Rzecz jasna, zachodnie dyskursy progresywistyczne, nieodmiennie nacechowane myśleniem utopijnym, mają swoje ambiwalentne dziedzictwo, o które można (i warto) spierać się także dzisiaj. Wydaje się, że w samym ich centrum tkwią przekonania o konieczności realizowania pewnego jasno nakreślonego i zdefiniowanego programu społecznego o charakterze emancypacyjnym i opartym na wartościach liberalnych. To, że takie poczucie misji - a przede wszystkim jego polityczne realizacje — przeżywa dzisiaj rozmaite kryzysy w świecie zachodnim (na wielu poziomach: od kryzysu demokracji reprezentatywnej do rozmontowania społecznego autorytetu nauki) nie jest bez znaczenia. W gruncie rzeczy, jak przekonuje Yuk Hui, jest to być może kolejny akord historycznych sprzeczności tkwiących w samym centrum zachodniego projektu oświeceniowego ${ }^{16}$. W tym kontekście niezbędne byłoby napisanie nowej historii kulturowej ruchów ekologicznych (liczba mnoga obejmuje tu zarówno ruchy ekologiczne, jak i historie) z uwzględnieniem perspektywy postkolonialnej i feministycznej. Byłoby to oczywiście przedsięwzięcie niezwykle trudne - musiałoby bowiem uwzględniać całe szeregi różnic kulturowych (choćby między trajektoriami rozwoju tych ruchów w Europie, Wielkiej Brytanii, Australii i Stanach Zjednoczonych, lecz także w Japonii, Indiach i krajach afrykańskich) oraz nierówności

${ }^{16}$ Y. Hui, On the unhappy consciousness of neoreactionaries, „e-flux” 2017, nr 81, https://www.e-flux.com/journal/81/125815/on-the-unhappy-consciousness-of-neoreactionaries/ (dostęp: 12.02.2019). 
w dostępie do władzy charakteryzowane w kategoriach wallersteinowskich. Niezwykle interesującym zjawiskiem, ogniskującym niemal wszystkie podjęte przeze mnie tutaj wątki, jest ruch permakulturowy, mający obecnie wymiar globalny, ale jednocześnie rozwijający wiele odmian: zróżnicowanych, lokalnych i zależnych od konkretnych bioregionów.

Redaktorzy wydanego w 2013 roku tomu poświęconego antropologii środowiskowej konstatują nie bez zdumienia, że w literaturze naukowej niewiele można znaleźć pozycji eksplorujących permakulturę jako przedmiot zainteresowania choćby właśnie antropologii ${ }^{17}$. Istotnie, jest to zaskakujące - zwłaszcza wobec wyrazistej obecności, szybkiego rozwoju na globalną skalę i trwałości ruchu permakulturowego przynajmniej od czasu, kiedy pod koniec lat siedemdziesiątych ukazały się pionierskie poradniki Billa Mollisona i Davida Holmgrena, uważane obecnie za swoiste dokumenty założycielskie ${ }^{18}$. Mollison i Holmgren, uznawani powszechnie za „ojców założycieli” ruchu, prowadzili swoją działalność w Australii przynajmniej od połowy lat siedemdziesiątych, co nie przeszkodziło w szybkim upowszechnieniu idei i (przede wszystkim) praktyki „trwałego rolnictwa" ${ }^{19}$ niemal na całym świecie, również poza krajami anglojęzycznymi, tradycyjnie postrzeganymi jako centralne.

Na przeszkodzie w szerszym zainteresowaniu tym ruchem przez academię stał być może wyraziście praktyczny wymiar permakultury, jej oparcie na określonych zasadach etycznych oraz mocna trans- i interdyscyplinarność. Projektowanie permakulturowe było w swoich początkach skupione przede wszystkim na ekologii systemowej, geografii krajobrazu i etnobiologii. Wyprzedzało ono w ten sposób dyskusje i praktyki ówczesnego świata akademickiego, wciąż przywiązanego do dyscyplinarnych rozróżnień (co - mimo licznych deklaracji i debat o inter- i transdyscyplinarności — do dzisiaj pozostaje w dużej mierze aktualne). Wśród wielu definicji permakultury przewijają się stałe elementy zwracające uwagę na zrównoważone formy gospodarowania. Choć na początku była to praktyka projektowania przede wszystkim trwałych i zrównoważonych agroekosystemów, w których rola człowieka była rozumiana jako partnerska wobec przyrody i których podstawą była przede wszystkim dogłębna obserwacja procesów i cykli naturalnych, to dzisiaj myślenie permakulturowe wykracza daleko poza praktyki ogrodnicze czy rolnicze.

17 J.R. Veteto, J. Lockyer, Environmental anthropology engaging permaculture: Moving theory and practice towards sustainability, [w:] Environmental Anthropology Engaging Ecotopia: Bioregionalism, Permaculture, and Ecovillages, red. J. Lockyer, J.R. Veteto, New York-Oxford 2013.

18 B. Mollison, D. Holmgren, Permaculture One, Sisters Creek 1978; B. Mollison, Permaculture: A Designer's Manual, Sisters Creek 1988; idem, Introduction to Permaculture, Sisters Creek 1991; D. Holmgren, Meliodora (Hepburn Permaculture Gardens): Ten Years of Sustainable Living, Hepburn 1996; idem, Permaculture: Principles \& Pathways Beyond Sustainability, Hepburn 2002.

${ }^{19}$ Anglojęzyczna nazwa permaculture powstała jako skrót od złożenia permanent agriculture ('trwałe rolnictwo') i podtytułu książki Russella Smitha, Tree Crops: A Permanent Agriculture, New York 1929. Warto wspomnieć, że istnieje jednak pewna różnica — Smith artykułował w 1929 roku zasadniczy problem swojej książki w kategoriach raczej „zachowania zasobów naturalnych” niż wzmocnienia bioróżnorodności, co nie umniejsza wartości jego praktycznych porad. 
Wydaje się, że umożliwiają to przede wszystkim bardzo spójne zasady etyczne, nastawione głównie na dbałość o utrzymanie bogatych systemów opartych na wzajemnych powiązaniach. Trzeba bowiem pamiętać, że jądrem każdego kursu projektowania permakulturowego jest właśnie podłoże etyczne - z niego wynikają bardzo konkretne rozwiązania do zastosowania w uprawie ziemi, lecz także w innych obszarach życia zawodowego, emocjonalnego czy rodzinnego. Sednem są tu trzy główne zasady: dbałość o ziemię (earthcare), dbałość o ludzi (peoplecare) oraz troska o równy podział (fair shares). Trzeba przy tym podkreślić, że ta druga zasada oznacza przede wszystkim nacisk na to, aby potrzeby ludzi były zaspokajane w sposób zrównoważony - tej tendencji zawsze towarzyszy dążenie do ograniczania indywidualnych potrzeb. Z kolei trzecia zasada została sformułowana przez Mollisona jako „ograniczanie konsumpcji i wzrostu populacji”, ale później — wobec krytyki wskazującej na możliwość eurocentrycznych jej interpretacji — przybrała formę zasad mówiących o „równym podziale” (faire shares), „ograniczaniu populacji i wykorzystaniu zasobów”, „redystrybucji naddatków” czy „,̇yciu w ramach ograniczeń" 20 .

Lobby Macnamara pisze raczej o dwóch aspektach tej trzeciej zasady — po pierwsze o respektowaniu ograniczeń środowiskowych (co oznacza przede wszystkim ograniczanie konsumpcji oraz przywiązywanie uwagi do tego, by praktyki konsumpcyjne były etyczne), po drugie o dzieleniu się nadmiarem (surplus) ${ }^{21}$. Towarzyszy temu przekonanie, że tak określana postawa etyczna oznacza także kultywowanie obfitości i nastawienie na obfitość. Obfitość jest tutaj definiowana jako oznaka zdrowego ekosystemu - ogrodnicy i działkowcy wiedzą o tym, że plony dają olbrzymią obfitość, której można sprostać, tylko dzieląc się z otoczeniem, nigdy zaś w pojedynkę. Natomiast życie nastawione przede wszystkim na niemal nieograniczoną indywidualną konsumpcję jest wyrazem nastawienia na brak (scarcity attitude) i przekonania, że ponieważ ograniczone zasoby nie wystarczą dla wszystkich, pojedyncze jednostki i rodziny muszą wygrywać w konkurencji o dostęp do nich.

Dzięki tej szczególnej etyce troski, na której zasadza się permakultura, nie jest ona po prostu zestawem konkretnych technik uprawy ziemi; o tym, czy coś jest permakulturowe, decyduje - oprócz praktyki - postawa etyczna (którą można rozpoznać po zastosowaniu pewnych rozwiązań, na przykład prowadzących do intensyfikacji plonów, ale zawsze $\mathrm{z}$ jednoczesnym wzmocnieniem bogactwa danego ekosystemu). Z tego też względu permakultura nie jest tylko formą rolnictwa ekologicznego. Sprowadzenie jej do tego wymiaru jest zdecydowanym zubożeniem. Można jednocześnie odwrócić to twierdzenie i powiedzieć, że samo rolnictwo ekologiczne to jeszcze nie permakultura. Jedno z nowszych podejść,

${ }^{20} \mathrm{~T}$. Long, The controversial third ethic of permaculture, 3.04.2017, https://permaculturenews. org/2017/04/13/controversial-third-ethic-permaculture/ (dostęp: 28.07.2019).

${ }^{21}$ L. Macnamara, People \& Permaculture: Caring and Designing for Ourselves, Each Other and the Planet, Hampshire 2012, s. 2. 
uwzględniające właśnie takie szersze znaczenie tego terminu, wykraczające poza uprawę ziemi, można znaleźć w książce Macnamary, która pisze: „Celem permakultury jest stworzyć harmonię między ludźmi i planetą” i streszcza następnie najważniejsze jej cechy w kilku punktach. Według niej permakultura:

— wykorzystuje naturę jako przewodnika,

— myśli całościowo,

- jest oparta na konkretnych rozwiązaniach,

— zasadza się na współpracy i powiązaniach,

— tworzy obfitość i harmonięe 22 .

Dalej autorka precyzuje: ,permakultura obejmuje w swoim jądrze zestaw zasad etycznych, które nas prowadzą, technik, które nam pomagają, metodykę kolejnych kroków w procesie projektowania, aby osiągnąć swoje cele oraz wezwanie do działania"23.

Wydaje się więc, że mamy tutaj do czynienia z typowym językiem misji. $\mathrm{W}$ istocie jednak metody działania permakulturowego są zupełnie odmienne przede wszystkim dlatego, że opierają się na etyce troski ${ }^{24}$, a za podstawowy warunek uznają konieczność uwzględniania konkretnego, lokalnego kontekstu.

Dlatego obok klasycznych już dzisiaj metod działania Mollisona i Holmgrena, które - jak wielokrotnie podkreślał Mollison - mają związek przede wszystkim z lokalnymi warunkami południowej półkuli (w wypadku Mollisona była to Tasmania), można spotkać zadrzewienia i lasy karmiące (food forest) czy ogrody z roślinami trwałymi (perennial garden) strefy umiarkowanej i borealnej. Odrębne sposoby postępowania charakteryzują strefę alpejską (i obszary górskie w ogóle) - tutaj do modelowych rozwiązań należą kontrowersyjne niekiedy działania Austriaka, Seppa Holzera, którego farma Krameterhof znajduje się w Alpach, na wysokości powyżej 1000 metrów n.p.m. ${ }^{25}$ Są także metody wykorzystujące warunki stref tropikalnych, strefy śródziemnomorskiej, stref pustynnych i półpu-

22 Ibidem. Język publikacji permakulturowych jest zazwyczaj bardzo prosty i przejrzysty, a książki mają charakter raczej poradnikowy. W przytoczonym fragmencie oddałam holistic jako „całościowy”, jako że polski odpowiednik ,holistyczny” zbytnio kojarzy się z dosyć mętnymi czasem wywodami ekofilozoficznymi, charakterystycznymi dla lat dziewięćdziesiątych XX wieku.

23 Ibidem.

24 Tę fundamentalną feministyczną perspektywę etyczną zaproponowała jeszcze w latach osiemdziesiątych Carol Giligan, aczkolwiek od tamtej pory propozycja ta zyskała szeroki oddźwięk w bardzo zróżnicowanych kontekstach i zainicjowała żywą dyskusję, także krytyczną wobec zbyt romantycznej wizji troski matczynej stanowiącej sedno propozycji Giligan wraz z krytyką artykułowaną między innymi z perspektywy badań nad niepełnosprawnością. Por. eadem, In a Different Voice: Psychological Theory and Women's Development, Cambridge-London 1993; R. Garland Thomson, Extraordinary Bodies: Figuring Physical Disability in American Culture and Literature, New York 1997; M. Sildrick, Monstrous Bodies: Encounters with Vulnerable Self, London 2001; V. Held, The Ethics of Care: Personal, Political, and Global, Oxford 2005.

25 S. Holzer, Permakultura Seppa Holzera. Praktyczne zastosowanie w ogrodnictwie, sadownictwie i rolnictwie, Lutynia 2014. 
stynnych, występują ponadto formy permakultur morskich i oceanicznych. Nie sposób w krótkim przeglądowym artykule zaprezentować całego ich zróżnicowania. Warto jednak podkreślić, że podstawą działalności jest zawsze wnikliwa i długotrwała obserwacja natury (a raczej konkretnego miejsca), a także wykorzystywanie tradycyjnych technik (w warunkach niedoborów będą to na przykład bardzo wyrafinowane sposoby wykorzystania wilgoci, tak zwana sucha irygacja, dobrze znana przynajmniej od VII wieku p.n.e. w Persji i w Azji Środkowej, rozpropagowana następnie w całym basenie Morza Śródziemnego przez Arabów ${ }^{26}$ ) i wspólnotowe formy gospodarowania (czasem w formie ekowiosek), oparte najczęściej na energii odnawialnej oraz wielokrotnym wykorzystywaniu materiałów. Bardzo ,permakulturowo” brzmi zatem hasło: Reuse, not recycle.

\section{Permakultura poza centrum, w środku kryzysów}

Nie sposób w krótkim tekście dokonać pełnego przeglądu całej różnorodności praktyk, podejść i rozwiązań, jakie generuje myślenie i projektowanie permakulturowe (i wbrew pozorom nie sprowadza się ono tylko do pewnych wybranych komponentów uznanych w wielu środowiskach za definiujące, jak wykorzystanie w jak największym zakresie energii odnawialnej, budowanie tak zwanych grzęd wyniesionych czy spirali ziołowych). I choć niektóre wskazania mogą brzmieć jak pop-psychologiczny coaching, to jednak różnią się od tej nowoczesnej formy wróżbiarstwa nastawieniem na działania skuteczne i pragmatyczne. Macnamara brzmi zatem wiarygodnie, kiedy proponuje, aby rozumieć odpowiedzialność jako „zdolność do odpowiedzi” (gra słów również w języku angielskim: responsability jako response-ability, czyli zdolność do wyboru odpowiedzi na warunki, w których się znajdujemy). Wiarygodność zasadza się bowiem na wielu praktycznych projektach, które sytuują rozwiązania permakulturowe w samym centrum współczesnych kryzysów. Ich przegląd przynosi ukazujący się w Wielkiej Brytanii od ponad dwudziestu pięciu lat „Permaculture Magazine”. Od tradycyjnych sposobów na regenerację gleby, wykorzystujących lokalną florę bakteryjną (inspirowanych koreańskim rolnictwem organicznym), po restoratywne leśnictwo na terenach zdegradowanych oraz regeneratywną hodowlę morską — niemal każdy numer przynosi paletę dowodów na to, że myślenie i projektowanie permakulturowe to „cicha rewolucja”, w dodatku skuteczna i oferująca konkretne scenariusze umożliwiające twórczą odpowiedź w najtrudniejszych nawet warunkach. Przyjrzenie się temu, jak etyka troski w obszarze permakultury jest modelowana nie na tradycyjnych społecznych rolach

26 M.M. Bahadori, Passive cooling systems in Iranian architecture, „Scientific American” 238, 1978, nr 2, s. 144-154; H.E. Wulff, The quanats of Iran, „Scientific American” 218, 1968, nr 4, s. 94-105. 
płciowych, lecz na szerszym spojrzeniu przekraczającym antropocentryzm oraz indywidualistycznie rozumianą rodzinę o tradycyjnych rolach płciowych, bliższą rozumieniu holobiontycznemu ${ }^{27}$ (w którym pojedynczy organizm jest rozumiany jako integralnie włączony we wspólnoty symbiotyczne) jest samo w sobie interesującym i wartościowym zadaniem badawczym.

Jednym z najwymowniejszych przykładów jest projekt realizowany przez Sector39 z Walii przy współpracy z ludźmi i organizacjami z Ugandy. Uganda w ciągu ostatnich trzech lat przyjęła bowiem blisko milion uchodźców z ogarniętego konfliktami zbrojnymi oraz dotkniętego zmianami klimatycznymi południowego Sudanu (szacuje się, że od 2013 roku, kiedy w Sudanie Południowym wybuchł konflikt zbrojny, do jesieni 2017 roku kraj opuściły 2 miliony ludzi). To oblicze kryzysu uchodźczego na skalę, o której w sytej i dostatniej Polsce nie mamy pojęcia. W wyniku porozumienia rządu Ugandy z agencjami międzynarodowymi zajmującymi się pomocą humanitarną uchodźcy otrzymują zazwyczaj niewielki skrawek ziemi (około $70 \mathrm{~m}^{2}$ ) i prawo do zbudowania domu, uprawy ziemi oraz dostęp do podstawowych usług medycznych i prawnych, dzięki którym mogą się osiedlić. Sector39 we współpracy z Permaculture Research Institute of Uganda rozpoczą w 2016 roku organizację kursów permakulturowych w ugandyjskich obozach dla uchodźców: Maaji oraz Bidi Bidi. Jak pisze jeden ze współorganizatorów, obozy dla uchodźców są widziane w perspektywie permakulturowej jako „centra nauki i innowacji”, ponieważ ludzie, którzy się tam znajdują, „są gotowi, aby zdobywać nowe umiejętności i perspektywy, nie ma tam zbyt wielu alternatyw ani rozpraszających rozrywek, są uważni odbiorcy, gotowi, żeby się uczyć"28. Przekazywaniu podstawowych zasad na temat tego, jak stymulować i wspierać naturalne procesy regeneracji gleby, jak najskuteczniej wykorzystywać wilgoć i zatrzymywać w glebie składniki odżywcze, towarzyszyły mikroprojekty o bardzo praktycznym charakterze. Były związane bezpośrednio z konkretnymi problemami, na jakie napotykają uczestnicy zajęć - na przykład grupa warsztatowa wspólnie opracowała, zaprojektowała i zbudowała prosty, przenośny i efektywny piec gliniany, który wymaga mniej paliwa, daje lepszy ogień i jest mobilny (co w wielu nomadycznych społecznościach Afryki subsaharyjskiej ma niebagatelne znaczenie). Zrealizowano ponad dziesięć praktycznych projektów w trakcie dwunastu dni zajęciowych, wszystko

${ }^{27}$ Holobiontyczna wizja życia, w której pojedyncze organizmy i ich ewolucja są zawsze włączone w szersze układy symbiotyczne, nie przyjmowała się łatwo, o czym świadczą trudności Lynn Margolis z publikacją jej fundamentalnych rozpoznań. Dzisiaj dostarcza podstaw do weryfikacji konceptualizacji pojedynczych organizmów. Na temat ewolucji zastosowań koncepcji holobiontycznej zob. S.F. Gilbert, Holobiont by birth: Multilineage individuals as the concretion of cooperative processes, [w:] Arts of Living on a Damaged Planet: Ghost and Monsters of the Anthropocene, red. A. Tsing et al., Minneapolis-London 2017, e-book, loc. 4194-4557. Wydaje się, że projektowanie permakulturowe od początku w pełni uwzględniało holobiontyczne rozumienie życia, zwracając szczególną uwagę na przykład na procesy glebotwórcze i regeneracyjne.

28 S. Jones, Changing lives in Ugandan refugee settlements, „Permaculture Magazine” 2019, nr 101, s. 25. 
w grupie w sumie czterdziestu osób (wśród których wiele było niepiśmiennych) pochodzących $\mathrm{z}$ dwunastu plemion i mówiących $\mathrm{w}$ sumie ośmioma różnymi językami. Absolwenci kursu zostali tak przygotowani, by móc następnie dzielić się wiedzą w swoich własnych społecznościach (jedną z permakulturowych zasad edukacyjnych jest stymulowanie procesów wzajemnego uczenia, zgodnie z zasadami peer-to-peer learning). Co ważne, nie był to jedyny projekt permakulturowy realizowany wśród uchodźców i z uchodźcami - ich przegląd można znaleźć w zasobach inicjatywy Permaculture for Refugees, której celem jest opracowywanie i tworzenie siedzib dla uchodźców na zasadach permakultury ${ }^{29}$. W omówionych studiach przypadku (od 2000 roku) można znaleźć przykłady z Macedonii, Grecji, południowych Włoch czy Tajlandii. Wszystkie ucieleśniają podstawowe zasady projektowania permakulturowego, którego jednym z filarów jest także „mocna tradycja transferu technologii i wiedzy poprzez różne tradycje kulturowe oraz oparcie na obserwacji empirycznej i eksperymentowaniu" ${ }^{30}$.

Praktyka projektowania permakulturowego jest nie tylko przykładem wspominanej tutaj wielokrotnie „cichej rewolucji”, odbywającej się niemal zupełnie poza gorącymi debatami medialnymi i poza światłem reflektorów. Wiele zasad wyznaczających fundamenty projektowania permakulturowego stanowi obecnie komponent licznych działań w mikroskali, na poziomie zmian indywidualnych wzorców konsumpcji, wspólnot sąsiedzkich, spółdzielni mieszkaniowych, miast i regionów, które - choć rozproszone i często postrzegane jak mało skuteczne — w rzeczywistości składają się na to, co można (z braku lepszego określenia) nazwać zmianą paradygmatu. Muszą im oczywiście towarzyszyć zmiany w innej skali, o charakterze działań, które poddają znaczącej krytyce logiki korporacyjne i polityki państw (od zmiany sposobów pozyskiwania energii elektrycznej po sprawiedliwy handel), ale permakultura pokazuje skuteczność nawet najdrobniejszych działań podejmowanych ze zrozumieniem całej sieci połączeń i współzależności, w które — żyjąc i umierając — nieustannie jesteśmy włączeni. Cechuje je przede wszystkim - oprócz wyrazistego programu etycznego, wiedzy ekologicznej i wrażliwości na inne formy życia obok nas — brak dogmatyzmu i ruchliwość wyobraźni, będąca pochodną niezwykle skutecznego łączenia refleksyjnej praktyki i usytuowanej teorii, w której zawsze jest miejsce na kontakt z ,gorącą pryzmą kompostową"31.

Jako taka może być ona odpowiedzią na agrologistykę ${ }^{32}$ i hiperbiekt (a właściwie ,przodka hiperobiektów”) o ludzkiej proweniencji, jakim według Mortona jest globalne, zmechanizowane przemysłowe rolnictwo, w istocie będące wstępem do antropocenu. Permakultura, koncentrując się na całości złożonych pro-

${ }^{29}$ Strona domowa inicjatywy: https://www.permacultureforrefugees.org (dostęp: 1.08.2019).

${ }^{30}$ J.R. Veteto, J. Lockyer, op. cit., s. 98.

31 D. Haraway, Staying With the Trouble: Making Kin in the Cthulucene, Durham-London 2016, e-book, loc. 343.

32 T. Morton, Dark Ecology: For A Logic of Future Coexistence, New York 2016. 
cesów, nie uprzywilejowuje obecności i nie ma linearnej logiki pomnażania; nie oferuje eliminowania niepewności, ale czerpie z niej i czyni z niej narzędzie poznania (zgodnie z zasadą „każdy problem jest jednocześnie rozwiązaniem”). $Z$ tej perspektywy zrozumiałe jest, dlaczego permakultura znika $\mathrm{z}$ radarów ferworu analitycznego ekologicznie zorientowanej i często ekologicznie „,narodzonej na nowo" i neofickiej academii. Jeśli zawierzyć Mortonowi, ,analityczne narzędzia humanistyki, które aktualnie mamy do dyspozycji, nie są zdolne do funkcjonowania w skali stosownej dla agrologistyki, ponieważ są same w sobie jej kompromisowymi produktami” "33. A permakultura znika do tego stopnia, że — choć wydaje się sytuować w samym centrum podskórnej, cichej rewolucji zachodzącej w sercu tego, co Morton nazywa agrologistyką — nie pojawia się ani razu na kartach jego książki o „ciemnej ekologii”, której zresztą może być jednym z symptomów.

\section{Watch, react, explore: Permaculture against agrologistics}

\section{Abstract}

In my article I aim at discovering how the potential of permaculture reaches out beyond the sustainable form of agricultural activity. I pay attention to the set of answers given to the current ecological crises, emphasizing the context-dependent, flexible and non-dogmatic ways of solving problems. Permaculture not only is a kind of practice aimed simultaneously at cultivating the land in a sustainable way and giving priority to creating an abundance of crops, but it also accounts for regenerative forestry, soil-making and agricultural practices maintaining the relationships with the older forms of inquiry, often inspired by indigenous knowledge. Therefore, I propose to outline the permacultural ethics and approach as a "mission without mission" and I set it against the modernist assumptions of what constitutes a socially progressive and environmentally sound activity.

Keywords: permaculture, ecological crises, agrologistics, anthropocene, transdisciplinarity

\section{Bibliografia}

Bahadori M.M., Passive cooling systems in Iranian architecture, „Scientific American” 238, 1978, nr 2. Bińczyk E., Epoka człowieka. Retoryka i marazm antropocenu, Warszawa 2018.

Baum, Hedlund, Aristei, Goldman, Where is Glyphosat banned?, https://www.baumhedlundlaw.com/ toxic-tort-law/monsanto- -roundup-lawsuit/where-is-glyphosate-banned/?fbclid=IwAR0cAkounL19rQxUz 06L5Fni-TN- kIA4NP8zN-0YTVO0--loi2JbJWR4HT4 (dostęp: 1.09.2019).

Carson R., Silent Spring \& Other Writings on the Environment, red. S. Steingraber, New York 2018.

Carson R., Crist M., A strange blight, „London Review of Books” 41, 2019, nr 11.

Franzen J., What if we stopped pretending, „New Yorker” 8.09.2019.

Giligan C., In a Different Voice: Psychological Theory and Women's Development, Cambridge-London 1993.

33 Ibidem, s. 43.

Prace Kulturoznawcze 23, 2019, nr 2-3

(C) for this edition by CNS 
Garland Thomson R., Extraordinary Bodies: Figuring Physical Disability in American Culture and Literature, New York 1997.

Gilbert S.F., Holobiont by birth: Multilineage individuals as the concretion of cooperative processes, [w:] Arts of Living on a Damaged Planet: Ghost and Monsters of the Anthropocene, red. A. Tsing, H. Swanson, E. Gan, N. Bubandt, Minneapolis-London 2017.

Haraway D., Staying With the Trouble: Making Kin in the Cthulucene, Durham-London 2016.

Held V., The Ethics of Care: Personal, Political, and Global, Oxford 2005.

Hirsch Hadorn G., Pohl Ch., Bammer G., Solving problems through transdisciplinary research, [w:] The Oxford Handbook of Interdisciplinarity, red. R. Frodeman, J. Thompson Klein, C. Mitcham, Oxford 2010.

Holmgren D., Meliodora (Hepburn Permaculture Gardens): Ten Years of Sustainable Living, Hepburn 1996.

Holzer S., Permakultura Seppa Holzera. Praktyczne zastosowanie w ogrodnictwie, sadownictwie i rolnictwie, Lutynia 2014.

Holmgren D., Permaculture: Principles \& Pathways Beyond Sustainability, Hepburn 2002.

Hui Y., On the unhappy consciousness of neoreactionaries, „e-flux” 2017, nr 81, https://www.e-flux. com/journal/81/125815/on-the-unhappy-consciousness-of-neoreactionaries/ (dostęp: 12.02.2019).

Jones L., Changing lives in Ugandan refugee settlements, „Permaculture Magazine” 2019, nr 101.

Keeling Ch.D., The concentration and isotopic abundances of carbon dioxide in the atmosphere, „Telus" $12,1960, \mathrm{nr} 2$.

Klein J.T., A taxonomy of interdisciplinarity, [w:] The Oxford Handbook of Interdisciplinarity, red. R. Frodeman, J. Thompson Klein, C. Mitcham, Oxford 2010.

Kolbert D., Szóste wymieranie. Historia nienaturalna, przeł. T. Grzegorzewska, P. Grzegorzewski, Warszawa 2016.

Long T., The controversial third ethic of permaculture, 3.10.2017, https://permaculturenews. org/2017/04/13/controversial-third-ethic-permaculture/ (dostęp: 28.07.2019).

Macnamara L., People \& Permaculture: Caring and Designing for Ourselves, Each Other and The planet, Hampshire 2012.

Massiot A., Jeux d'influence, l'affaire Monsanto revisitée en série, „Libération” 7.06.2019, https:// www.liberation.fr/planete/2019/06/07/jeux-d-influence-1-affaire-monsanto-revisitee-en-serie_1732055 (dostęp: 28.06.2019).

Mollison B., Introduction to Permaculture, Sisters Creek 1991.

Mollison B., Permaculture: A Designer's Manual, Sisters Creek 1988.

Mollison B., Holmgren D., Permaculture One, Sisters Creek 1978.

Morton T., Dark Ecology: For A Logic of Future Coexistence, New York 2016.

Nacher A., Rubieże kultury popularnej. Popkultura w świecie przeptywów, Poznań 2012.

Sildrick M., Monstrous Bodies: Encounters with Vulnerable Self, London 2001.

Smith J.R., Tree Crops: A Permanent Agriculture, New York 1929.

Solnit R., Nadzieja w mroku, przeł. A. Dzierzgowska, S. Królak, Kraków 2019.

Veteto J.R., Lockyer J., Environmental anthropology engaging permaculture: Moving theory and practice towards sustainability, [w:] Environmental Anthropology Engaging Ecotopia: Bioregionalism, Permaculture, and Ecovillages, red. J. Lockyer, J.R. Veteto, New York-Oxford 2013.

Thant U., Problems of the human environment; report of the Secretary General, dokumenty ONZ $\mathrm{E} / 4667$.

Wulff H.E., The quanats of Iran, „Scientific American” 218, 1968, nr 4.

Prace Kulturoznawcze 23, 2019, nr 2-3

(C) for this edition by CNS 